\title{
LARANGAN BERCADAR DI PERGURUAN TINGGI PERSPEKTIF SADD AL-DZARÎ'AH
}

\author{
Toha Andiko \\ Fakultas Syariah, Institut Agama Islam Negeri (IAIN) Bengkulu \\ J. Raden Fatah Pagar Dewa Bengkulu \\ E-mail: toha.andiko@gmail.com
}

\begin{abstract}
The Prohabitions on Wearing Niqab (Face Covers for Mulism Women) in Higher Education Perspectives of Sadd al-dzarî ah. Wearing niqab for women in colleges has recently become a polemic. This happened after two Islamic universities in Indonesia made a policy of prohibition for the academic community to wear the niqab on campus. Pros cons arise to address the policy of the rector II college. In the study of Jurisprudence, Hanafi, Maliki, and Shafi'i schools agree that women's faces are not aurat (private parts of human's body that cannot be exposed or should be covered according to Islam). Only the Hambali school of thought which says that the whole body of a woman, including the face, is aurat. Therefore, outside the prayers only Hambali schools that require covering the face for women by using niqab. While the other three schools of thought argue that wearing niqab is considered Sunnah (the way of the prophet), and can become mandatory if it is feared to cause slander. Since wearing niqab is categorized a khilafiah, the universities is entitled to establish a policy which prohibits its students to wear niqab: as long as this is believed and based on the strong and real reasons for its positive impact on the college and the student themselves. This action may be justified and appropriate under the sadd al-dzarîah proposition, as a preventive and anticipatory measure to prevent potential harm and damage that will result from wearing the veil on campus.
\end{abstract}

Keywords: wearing niqab ban; higher education; sadd al-dzarî‘ah.

Abstrak: Larangan Bercadar di Perguruan Tinggi Perspektif Sadd al-Dzarîah. Pemakaian cadar bagi wanita di perguruan tinggi baru-baru ini menjadi polemik. Ini terjadi setelah dua perguruan tinggi Islam di Indonesia membuat kebijakan larangan bagi civitas akademikanya untuk menggunakan cadar selama di kampus. Pro kontra bermuculan menyikapi kebijakan rektor dua perguruan tinggi tersebut. Dalam kajian fikih, Mazhab Hanafi, Maliki, dan Syafi i sepakat berpendapat bahwa wajah wanita bukanlah aurat. Hanya mazhab Hambali yang berpendapat bahwa seluruh tubuh wanita, termasuk wajah adalah aurat. Oleh sebab itu, di luar salat hanya mazhab Hambali yang mewajibkan menutup wajah bagi wanita dengan menggunakan cadar. Sedangkan tiga mazhab yang lain berpendapat hukumnya sunah, dan bisa menjadi wajib jika dikhawatirkan menimbulkan fitnah. Karena masalah cadar ini termasuk kategori khilafiah, maka perguruan tinggi berhak menetapkan kebijakan yang melarang mahasiswinya untuk bercadar, selama diyakini dan didasari alasan yang kuat dan nyata dampak positifnya bagi perguruan tinggi maupun mahasiswi itu sendiri. Tindakan ini bisa dibenarkan dan sesuai berdasarkan dalil sadd al-dzarî̀ah, sebagai langkah preventif dan antisipatif untuk mencegah potensi bahaya dan kerusakan yang akan ditimbulkan dari pemakaian cadar tersebut di kampus.

Kata kunci: larangan bercadar; perguruan tinggi; sadd al-dzarî‘ah.

\section{Pendahuluan}

Pada bulan Februari 2018, masyarakat muslim di Indonesia dihebohkan dengan berita tentang larangan bercadar bagi mahasiswi yang kuliah di UIN Sunan Kalijaga Yogyakarta. Ini berdasarkan Surat Rektor No B-1301/Uno2/R/AK.00.3/02/2018 tentang Pembinaan Mahasiswi Bercadar. Dalam paparan kebijakan kepada media di Yogyakarta,
Rektor UIN Sunan Kalijaga Prof. Yudian Wahyudi menjelaskan bahwa sebagai kampus negeri, UIN merasa wajib menjaga Indonesia. Kebijakan ini, kata Yudian juga untuk menyelamatkan mahasiswi bersangkutan. "Kami ingin menyelamatkan republik, tetapi yang secara langsung adalah mahasiswi yang mengenakan cadar ini. Karena seringkali mereka tidak mengerti, dikira versi 
yang disampaikan kepada mereka itu kebenaran mutlak. Padahal ini lebih banyak terkait dengan tradisi atau budaya. Seringkali mereka tidak mengetahuinya."

Jika ditelusuri lebih lanjut, yang melatarbelakangi keluarnya larangan pemakaian cadar di lingkungan kampus adalah beredarnya foto belasan mahasiswi bercadar tengah mengibarkan bendera salah satu organisasi Islam di kampus. Sebab, beberapa hari setelah foto itu beredar luas, rektor UIN memutuskan harus melakukan pembinaan lewat konseling. Jika setelah proses itu para mahasiswi tersebut tetap mempertahankan cadarnya, maka kampus berencana mengeluarkan mereka.

Kasus yang mirip terjadi juga di IAIN Bukittinggi berkaitan dengan dinonaktifkannya dosen bahasa Inggris bernama Dr. Hayati Syafri, S.S, M.Pd. terhitung mulai Februari 2018 karena bercadar. Rektor IAIN Bukittinggi, Ridha Ahida menyatakan bahwa aturan tentang larangan bercadar di kampus itu berdasarkan otonomi kampus. Bahkan dalam konferensi pers di kampus tersebut pada Jumat, 16 Maret 2018, Ridha bersikukuh bahwa IAIN Bukittinggi akan menjalankan kode etik tersebut. Sebab menurutnya kode etika berbusana merupakan kesepakatan dari mayoritas akademika kampus. Selain itu, ia menjelaskan pula bahwa setiap perguruan tinggi memiliki otonomi atau hak mengelola lembaga pendidikannya. Hal tersebut diatur dalam UU Nomor 12 tahun 2012 dan Peraturan Pemerintah nomor 4 tahun 2014 tentang Pengelolaan Perguruan Tinggi. Karena perguruan tinggi memiliki otonomi untuk mengelola sendiri lembaganya sebagai pusat penyelenggaraan Tri Dharma Perguruan Tinggi, maka dari itu IAIN Bukittinggi memiliki statuta, pedoman akademik, dan kode etik dosen dan mahasiswa. Dalam kode etik berbusana, Ridha menjelaskan bahwa aturan yang diberlakukan di IAIN Bukittinggi harus berpakaian formal dan sesuai dengan syariat Islam. Sedangkan cadar, tidak termasuk pakaian yang formal bagi IAIN Bukittinggi. ${ }^{2}$

\footnotetext{
1 https://www.voaindonesia.com/a/banyak-pihak-tentanglarangan-pemakaian-cadar-di-uni-sunan-kalijaga-/4288811.html, diakses 29 Maret 2018

2 https://www.kiblat.net/2018/03/17/iain-bukittinggibersikukuh-larang-cadar-di-kampus/, diakses 1 April 2018
}

Pro dan kontra lalu bermunculan terhadap dua kebijakan rektor dari perguruan tinggi keagamaan Islam negeri tersebut. Bagi yang mendukung kebijakan pelarangan cadar di kampus, mereka beralasan bahwa pelarangan itu sah dan dimaksudkan untuk kepentingan umum dan kampus serta kebaikan mahasiwi itu sendiri. Sedangkan bagi yang menolak kebijakan larangan bercadar di kampus, mereka beralasan bahwa larangan tersebut bertentangan dengan hak asasi manusia, di samping itu tidak ada satu pun dalil dari Alquran dan hadis yang melarang muslimah bercadar. Oleh sebab itu, perlu kiranya mengkaji lebih jauh terkait dengan larangan penggunaan cadar di perguruan tinggi dalam tinjauan sadd al-dzari ah sebagai salah satu dalil yang diakui dalam istinbath hukum Islam.

\section{Cadar Sebagai Pakaian: Historis dan Kultural}

Pada masa Jahiliyah dan awal masa Islam, wanita-wanita di Jazirah Arab memakai pakaian yang pada dasarnya mengundang kekaguman pria, di samping untuk melindungi dari udara panas yang merupakan iklim umum padang pasir. Mereka memakai kerudung, tapi kerudung tersebut sekedar diletakkan di kepala dan biasanya terulur ke belakang, sehingga dada dan kalung yang menghiasi leher mereka tampak dengan jelas. Bahkan boleh jadi sedikit dari daerah buah dada dapat terlihat karena longgar atau terbukanya baju mereka itu. Telinga dan leher mereka juga dihiasi anting dan kalung. Celak sering mereka gunakan untuk menghiasi mata mereka. Kaki dan tangan mereka dihiasi dengan gelang yang bergerincing ketika berjalan. Telapak tangan dan kaki mereka sering kali juga diwarnai dengan pacar. Alis mereka pun dicabut dan pipi mereka dimerahkan, tak ubahnya seperti wanitawanita masa kini, walau cara mereka masih sangat tradisional. Mereka juga memberi perhatian terhadap rambut yang sering kali mereka sambung dengan guntingan rambut wanita lain. Namun setelah Islam datang, Alquran dan sunah berbicara tentang pakaian dan memberi tuntunan menyangkut cara-cara memakainya. ${ }^{3}$

3 Muhammad Quraish Shihab, Jilbab Pakaian Wanita Muslimat, (Jakarta: Lentera Hati, 2014), h. 48. 
Secara historis, wanita muslimah pada masa awal Islam di Madinah memakai pakaian yang sama dengan wanita umumnya, termasuk wanita tunasusila atau hamba sahaya. Mereka memakai baju dan kerudung atau jilbab, namun dada dan leher mereka terbuka, tidak jarang juga mereka memakai kerudung tapi ujungnya dikebelakangkan hingga telinga, leher, dan sebagaian dada mereka terlihat. Sehingga tidak jarang orang munafik mengganggu wanita muslimah dengan mengatakan "Kami kira hamba sahaya". Dalam kondisi seperti inilah turun surat al-Ahzab[33] ayat 59 tentang pemakaian jilbab yang bermakna baju kurung yang longgar. Ayat ini secara jelas menuntut kaum muslimah untuk memakai pakaian yang membedakan mereka dengan yang bukan muslimah, ini dimaksudkan agar identitas mereka jelas, dan menghindari gangguan dari orangorang yang usil. ${ }^{4}$

Muhammad Quraish Shihab sebagai mufassir modern Indonesia yang biasa menulis tafsir secara maudhu'i (tematik), menguraikan pakaian dalam bukunya "Wawasan Alquran". Ketika menguraikan kata libas di dalam Alquran yang berarti penutup, baginya fungsi pakaian sebagai penutup sangat jelas. Tapi tidak harus berarti menutup aurat, sebab secara kebahasaan, cincin yang menutup sebagian jari juga disebut libas, pemakainya ditunjuk dengan menggunakan akar katanya dari surat al-Nahl[16] ayat 14. Dan dari beberapa ayat Alquran, paling tidak dapat disimpulkan empat fungsi pakaian. Pertama, sebagai penutup aurat (Al-A 'raf[7]: 26), kedua, sebagai perhiasan, ketiga sebagai fungsi takwa yang dapat menghindarkan seseorang terjerumus ke dalam bencana dan kesulitan baik di dunia maupun di akhirat (AlNahl[16]: 81). Keempat, sebagai petunjuk identitas dan pembeda antara seseorang dengan yang lain. ${ }^{5}$

Selanjutnya yang menjadi diskursus ulama tafsir adalah kalimat illa ma zhara minha (alNur[24]: 31). Kata illa adalah istitsna' muttashil yang bermakna dikecualikan adalah bagian dari apa yang disebut sebelumnya, sehingga ayat itu mengandung pesan "Hendaknya wanita-wanita

4 Faisar Ananda Arfa, Wanita Dalam Konsep Islam Modernis, (Pustaka Firdaus, 2014), h. 75.

5 Muhammad Quraish Shihab, Wawasan Al-Qur'an, (Bandung: Mizan, 2013), Cet. ke-19, h. 89. tidak menampakkan hiasan (anggota tubuh) mereka kecuali apa yang kelihatan". Dari redaksi ini lalu lahir tiga pendapat dalam pemahamannya. Pertama, memahami kata illa dalam arti istitsna munqathi` artinya yang dikecualikan bukan bagian yang disebut sebelumnya. Ini berarti "janganlah mereka menampakkan hiasan mereka, tetapi apa yang tampak (secara sengaja/tidak sengaja) maka itu dimaafkan". Kedua, menyisipkan kalimat dalam penggalan ayat itu sehingga berbunyi: "janganlah mereka menampakkan hiasan mereka (badan mereka), mereka berdosa jika demikian. Tetapi jika tampak tanpa disengaja, maka mereka tidak berdosa". Yang ketiga, memahami "kecuali apa yang nampak" dalam arti apa yang biasa dan atau dibutuhkan keterbukaannya sehingga harus tampak". Kebutuhan di sini berarti menimbulkan kesulitan bila bagian tersebut ditutup. Mayoritas ulama memahami penggalan ayat tersebut dalam ayat ketiga ini.

Al-Qurthubi dalam tafsirnya mengemukakan bahwa ulama besar Said bin Jubair, Atha', dan al-Auza i berpendapat bahwa yang boleh dilihat hanya wajah wanita, kedua telapak tangan dan busana yang dipakainya. Ibnu Abbas, Qatadah, dan Miswar bin Makhzamah berpendapat yang boleh termasuk juga celak mata, gigi, anting, cincin, dan lainnya. ${ }^{6}$ Muhammad Ali al-Sayis mengemukakan bahwa menurut Abu Hanifah kedua kaki juga bukan aurat, sebab lebih menyulitkan bagi wanita-wanita di pedesaan yang harus berjalan kaki tanpa alas untuk memenuhi kebutuhan mereka. Begitu juga Abu Yusuf yang berpendapat bahwa kedua tangan wanita bukan aurat, sebab menurutnya akan menyulitkan wanita. Padahal, dalam Alquran kesulitan merupakan faktor yang melahirkan kemudahan. ${ }^{7}$ Dengan mengutip ibnu Athiyah yang menyatakan bahwa berdasarkan redaksi ayat, wanita diperintahkan untuk tidak menampakkan dan berusaha menutup sesuatu yang berupa hiasan, pengecualian berlaku berdasarkan keharusan melakukan gerakan atau untuk melakukan kebaikan. Di sini Quraish Shihab berkomentar, bila rumusan ini diterima,

${ }^{6}$ Muhammad ibn Ahmad ibn Abi Bakr Farh al-Qurthubi, al-Jami' li Ahkâm al-Qur'ân, (Mesir: Dar al-Sya 'bi, 1372 H), h. 165

7 Muhammad Ali al-Sayis, Tafsîr Ayât al-Ahkâm, (Beirut: Dâr al-Fikr, t. th), h. 79 
maka pengecualian itu dapat berkembang sesuai dengan kebutuhan yang mendesak yang dialami seseorang. Selanjutnya Ibnu `Asyur berkata bahwa cara memakai jilbab berbeda-beda sesuai dengan pemakaian wanita dan adat mereka. Namun, tujuan perintah ini adalah agar mereka dapat dikenal sebagai wanita muslimah yang baik sehingga tidak diganggu." Adapun mengenai redaksi perintah (amar) dalam ayat, bukankah tidak semua perintah yang tercantum dalam Alquran melahirkan hukum wajib? Salah satu contoh adalah perintah mencatat hutang piutang (Al-Baqarah[2]: 282). Begitu juga perintah dalam hadis yang mengandung makna "sebaiknya", bukan seharusnya, ${ }^{8}$ kecuali ada qarinah lain yang mendukungnya.

Jika menelusuri asal-usul wanita memakai cadar, cadar adalah pakaian yang digunakan untuk menutupi wajah, minimal untuk menutupi hidung dan mulut. ${ }^{9}$ Umat Islam di luar daerah Arab sudah mengenal cadar (niqab) dari salah satu penafsiran ayat Alquran di surat al-Nur[24]: 31 dan surat Al-Ahzab[33]: 59 yang diuraikan oleh sebagian sahabat Nabi. Terkait sebab turunnya surat alAhzab[33]: 59 disebutkan dalam suatu riwayat bahwa Siti Saudah (istri Rasulullah) keluar rumah untuk sesuatu keperluan setelah diturunkan ayat hijab. la adalah seorang yang badannya tinggi besar sehingga mudah dikenali orang. Pada waktu itu Umar melihatnya, dan ia berkata: "Hai Saudah, demi Allah, bagaimana pun kami akan dapat mengenalmu. Karenanya cobalah pikir mengapa engkau keluar?" Dengan tergesa-gesa ia pulang dan saat itu Rasulullah berada di rumah Aisyah sedang memegang tulang sewaktu makan. Ketika masuk ia berkata: "Ya Rasulullah, aku keluar untuk sesuatu keperluan, dan Umar menegurku (karena ia masih mengenalku)". Karena peristiwa itulah turun ayat ini (surat al-Ahzab[33]: 59) kepada Rasulullah saw. Di saat tulang itu masih di tangannya, maka Rasulullah lalu bersabda: "Sesungguhnya Allah telah mengizinkan engkau keluar rumah untuk sesuatu keperluan." ${ }^{10}$ Dalam riwayat lain dikemukakan bahwa istri-

\footnotetext{
${ }^{8}$ Muhammad Quraish Shihab, Wawasan Al-Qur'an..., h. 127

${ }_{9}$ Muhammad Sayyid Thanthawi, al-Tafsîr al-Wasith Li alQur'ân al-Karîm, (Kairo: Dar al-Sa'adah, 1985), Juz. 11, h. 207.

${ }^{10}$ K.H.Q. Shaleh, dkk, Asbabun Nuzul, (Bandung: Diponegoro, 2017), h. 443.
}

istri Rasulullah saw. pernah keluar malam untuk mengqadha hajat (buang air). Pada waktu itu orang-orang munafik mengganggu mereka dan menyakiti. Hal ini diadukan kepada Rasulullah saw., sehingga Rasul menegur orang-orang munafik tersebut. Mereka menjawab: "Kami hanya mengganggu hamba sahaya”. Maka turunnya ayat ini (surat al-Ahzab[33]: 59) sebagai perintah untuk berpakaian tertutup, agar berbeda dari hamba sahaya. ${ }^{11}$

Abdul Halim Abu Syuqqah menyatakan bahwa cadar (niqab) merupakan bagian dari salah satu jenis pakaian yang digunakan oleh sebagian perempuan di masa Jahiliyah. Kemudian model pakaian ini berlangsung hingga masa Islam. Nabi Muhammad saw tidak mempermasalahkan model pakaian tersebut, tetapi tidak sampai mewajibkan, menghimbau ataupun menyunahkan cadar kepada perempuan. Seandainya cadar dianggap sebagai pakaian yang dapat menjaga marwah perempuan dan sebagai sarana untuk menjaga keberlangsungan hidup mereka--sebagaimana klaim sejumlah pihak, tentu Nabi Muhammad saw akan mewajibkannya kepada isteri-isterinya, karena mereka (isteri-isteri Nabi) adalah keluarga yang paling berhak untuk dijaga oleh Nabi. Namun kenyataannya justru Nabi tidak melalukannya. Ini juga tidak berlaku bagi sahabat-sahabat perempuan Nabi. Hal ini merupakan bukti bahwa niqab--meskipun terus ada hingga di masa Islam--hanyalah sebatas jenis pakaian yang dikenal dan dipakai oleh sebagian perempuan. Kemudian bagi ummahat al-mukminin (isteri-isteri Nabi) memiliki perbedaan, mereka dikhususkan atas kewajiban mengenakan hijab di dalam rumah dan menutup semua badan dan wajahnya ketika keluar dari rumah sebagai bentuk memperluas hijab yang diwajibkan di dalam rumah. ${ }^{12}$ Oleh sebab itu, cadar hanyalah bagian dari pakaian yang dikenakan oleh sebagian perempuan Arab, baik dari pra Islam maupun setelahnya. Tidak ada perintah khusus mengenai pakaian ini, baik kewajiban maupun kesunahannya. ${ }^{13}$

${ }^{11}$ Nashrudin Baidan, Tafsir bi al-Ra'yi, (Yogyakarta: Pustaka Pelajar, 2009), h. 120.

${ }^{12}$ Abdul Halim Abu Syuqqah, Al-Niqâb fi Syari'at al-Islam, (Beirut: Dar al-Fikr, 2008), h. 48.

${ }^{13}$ Abdul Halim Abu Syuqqah, Tahrir al-Mar'ah fi 'Ashr alRisalah, vol. IV, h. 220. 
Menurut penelitian M. Qurash Shihab, memakai pakaian tertutup termasuk cadar bukanlah monopoli masyarakat Arab, dan bukan pula berasal dari budaya mereka. ${ }^{14}$ Bahkan menurut ulama dan filosof besar Iran kontemporer, Murtadha Muthahhari, pakaian penutup seluruh badan wanita termasuk cadar telah dikenal di kalangan bangsa-bangsa kuno, jauh sebelum datangnya Islam, dan lebih melekat pada orangorang Persia, khususnya suku Sassan di Iran. Dibandingkan dengan di tempat-tempat lain, bahkan mereka lebih keras tuntutannya daripada yang diajarkan Islam. ${ }^{15}$ Sedang menurut pendapat lainnya menambahkan, orang-orang Arab meniru orang Persia yang mengikuti agama Zardayst yang menilai wanita sebagai makhluk tidak suci, karena itu mereka diharuskan menutup mulut dan hidungnya dengan sesuatu agar nafas mereka tidak mengotori api suci yang merupakan sesembahan agama Persia lama. Orang-orang Arab meniru juga masyarakat Byzantium (Romawi) yang memingit wanita di dalam rumah, ini bersumber dari masyarakat Yunani kuno yang ketika itu membagi rumah-rumah mereka menjadi dua bagian, masing-masing berdiri sendiri, satu untuk pria dan satu lainnya untuk wanita. Di dalam masyarakat Arab, tradisi ini menjadi sangat kukuh pada saat pemerintahan Dinasti Umawiyah, tepatnya pada masa pemerintahan al-Walid II (125 H/747 M), di mana penguasa ini menetapkan adanya bagian khusus buat wanita di rumah-rumah. ${ }^{16}$

\section{Hukum Bercadar Perspektif Empat Mazhab}

Wanita bercadar seringkali diidentikkan dengan orang Arab atau Timur Tengah. Padahal, memakai cadar atau menutup wajah bagi wanita adalah ajaran Islam yang didasari dalil-dalil Alquran, hadis sahih, dan penerapan para sahabat Nabi saw serta para ulama yang mengikuti mereka. Sehingga tidak benar anggapan bahwa hal tersebut merupakan sekedar budaya. Meski

14 Shihab, Jilbab Pakaian Wanita Muslimat, (Jakarta: Lentera Hati, 2014), h. 48.

15 Murtadha Muthahari, Gaya Hidup Wanita Islam, terj. Agus Efendi, Alwiyah Abdurrahman, (Bandung, Mizan, 1990), h. 34 .

${ }^{16}$ Hasan al-'Audah, al-Mar'ah al-'Arabiyah Fi al-Din wa alMujtama', (Beirut: al-Ahaly, 2000), h. 101-102 demikian, dalam tataran praksisnya penggunaan cadar tidak bisa dilepaskan dari konteks sosial dan budaya masyarakat setempat. Artinya, penggunaan cadar di sebuah daerah yang memiliki kultur yang cocok dengan pakaian tersebut, hal ini tidak menjadi masalah. Sebaliknya, penggunaan cadar di daerah lain dengan kultur yang berbeda dengan kultur Arab, misalnya di Indonesia, yang tidak memiliki tradisi penggunaan cadar bagi perempuan, hukum mengharuskan penggunaan cadar bisa jadi berbeda.

Secara yuridis, dalam kajian fikih para ulama berbeda pendapat tentang hukum memakai cadar. Perbedaan pendapat ini terjadi karena perbedaan penafsiran dan pemahaman mereka terhadap ayat-ayat dan hadis-hadis yang menjelaskan tentang jilbab, khimar, dan niqab. Perdebatan para ahli fikih mengenai hukum penggunaan cadar memiliki keterkaitan dengan persoalan batas aurat bagi perempuan. Dari sinilah khilafiyah mengenai hal ini tidak bisa dihindari. ${ }^{17}$

Pada dasarnya, penggunaan cadar hukumnya adalah mubah. Ini tampak dari pernyataan:

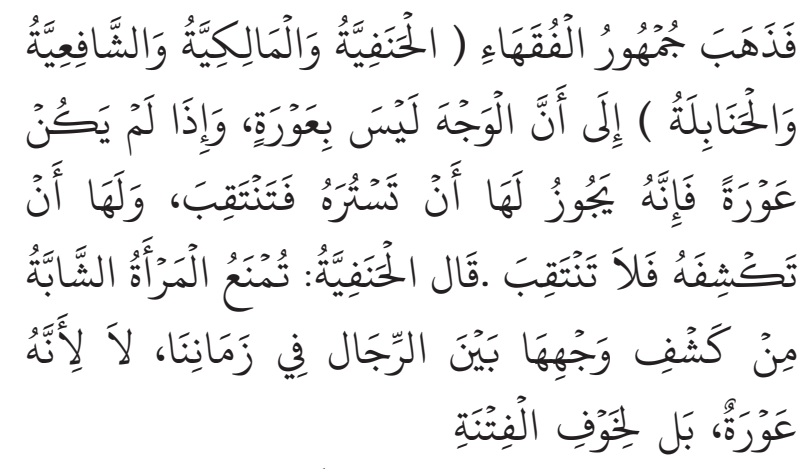

"Mayoritas fuqaha (baik dari mazhab Hanafi, Maliki, Syafi'i, dan Hanbali) berpendapat bahwa wajah bukan termasuk aurat. Jika demikian, wanita boleh menutupinya dengan cadar dan boleh membukanya.

Menurut mazhab Hanafi, untuk zaman sekarang bagi wanita muda (al-mar'ah al-syabbah) dilarang memperlihatkan wajah di antara lakilaki. Bukan karena wajah itu sendiri adalah aurat, tetapi lebih karena untuk menghindari fitnah,"18 Ini tampak dari pernyataan beberapa ulama mereka, di antaranya al-Syaranbalali yang mengatakan:

${ }^{17}$ Ramadhan al-Buthi, Ila Kulli Fatat Tu'min Billah, (Damaskus: Maktabah Al-Farabi, t.th), h. 30

${ }^{18}$ Lihat Al-Mawsu'atul Fighiyyah al-Kuwaitiyyah, (Kuwait: Wizaratul Awqaf was Syu'unul Islamiyyah, t.th), juz XLI, h. 134 


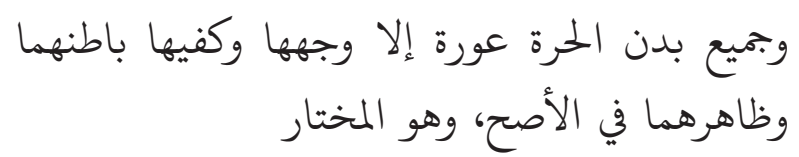

"Seluruh tubuh wanita adalah aurat kecuali wajah dan telapak tangan dalam serta telapak tangan luar, ini pendapat yang lebih sahih dan merupakan pilihan mazhab kami"“19

Al-Hashkafi berpendapat bahwa:

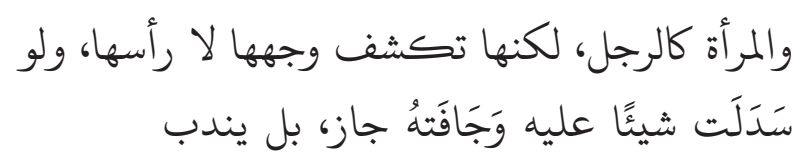

"Aurat wanita dalam salat itu seperti aurat lelaki. Namun wajah wanita itu dibuka sedangkan kepalanya tidak. Andai seorang wanita memakai sesuatu di wajahnya atau menutupnya, boleh, bahkan dianjurkan"2o

Ibnu Abidin berpendapat bahwa:

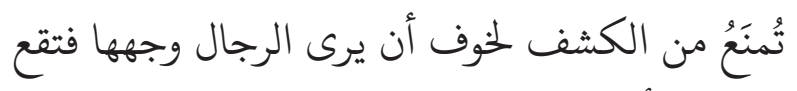
الفتنة، لأنه مح الكشف قد يقح النظر إليها بشهوة "Dilarang bagi wanita menampakan wajahnya karena khawatir akan dilihat oleh para lelaki, kemudian timbullah fitnah. Karena dengan wajah yang dinampakkan, bisa jadi lelaki melihatnya dengan syahwat"21

Zainuddin bin Ibrahim bin Muhammad yang populer dengan sebutan Ibnu Najim al-Mishri al-Hanafi menambahkan:

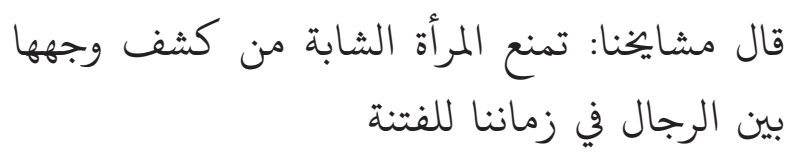

"Para ulama mazhab kami berkata bahwa dilarang bagi wanita muda untuk menampakkan wajahnya di hadapan para lelaki pada zaman kita, karena dikhawatirkan menimbulkan fitnah". ${ }^{22}$

Dengan demikian, dalam mazhab Hanafi, pada prinsipnya wajah wanita bukanlah aurat, namun memakai cadar hukumnya sunah (dianjurkan) dan menjadi wajib jika dikhawatirkan menimbulkan fitnah.

${ }_{19}$ Abu al-Ikhlas al-Hasn ibn Ammar ibn Ali ibn Yusuf alSyaranbalali, Nur al-Idhâh, (Beirut: Dar al-Fikr, t.th), h. 123

${ }^{20}$ Muhammad bin Aly Al Haskafy 'Ala' al-Din, Al-Durr alMukhtâr Syarh Tanwir al-Abshâr, (Lebanon: Dar al-Kutub alIlmiyah, 1423 H), Juz 2, h.189

${ }_{21}$ Ibnu 'Abdin, Hasyiah Rad al Mukhtâr 'ala al-Durr al Mukhtâr Syarh Tanwir al Abshâr, (Riyadh: Dar al-Alam alKutub,t. th), Juz III, h.188-189.

${ }^{22}$ Zainuddin bin Ibrahim bin Muhammad, Al-Bahr Ar-Ra'iq Syarh Kanz al-Daqâ'iq, (Iskandaria: Dar al-Iman, 1990), h. 284.
Menurut mazhab Maliki, wajah wanita bukanlah aurat, namun memakai cadar hukumnya sunah (dianjurkan) dan menjadi wajib jika dikhawatirkan menimbulkan fitnah. Bahkan sebagian ulama mazhab Maliki berpendapat seluruh tubuh wanita adalah aurat. Namun di sisi lain, mereka berpendapat bahwa wajib menutupi dua telapak tangan dan wajah bagi wanita muda yang dikhawatirkan menimbulkan fitnah, ketika ia adalah wanita yang cantik atau dalam situasi banyak munculnya kebejatan atau kerusakan moral. Ini bisa dipahami dari penyataan:

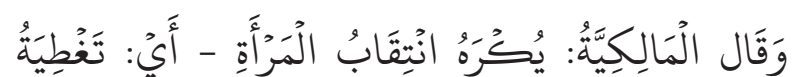

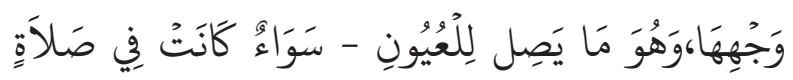

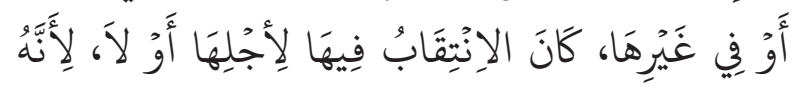

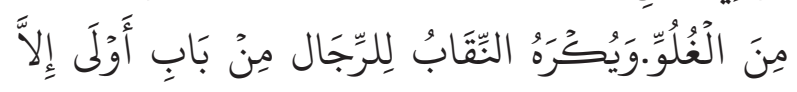

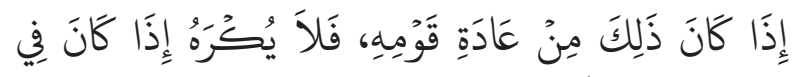

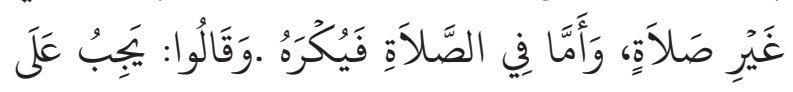

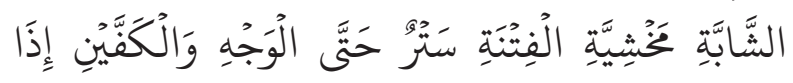

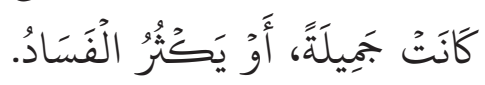

"Dan mazhab Maliki berpendapat bahwa dimakruhkan wanita memakai cadar-artinya menutupi wajahnya sampai mata-baik dalam salat maupun di luar salat atau karena melakukan salat atau tidak, karena hal itu termasuk berlebihan (ghuluw). Dan lebih utama cadar dimakruhkan bagi laki-laki kecuali ketika hal itu merupakan kebiasaan yang berlaku di masyarakatnya, maka tidak dimakruhkan ketika di luar salat. Adapun dalam salat maka dimakruhkan. Mereka menyatakan bahwa wajib menutupi kedua telapak tangan dan wajah bagi perempuan muda yang dikhawatirkan bisa menimbulkan fitnah, apabila ia adalah wanita yang cantik, atau maraknya kebejatan moral," 23

Ini dikuatkan lagi oleh Ibnu Arabi yang mengatakan:

والمرأة كلها عورة، بدنها، وصوتها، فلا يجوز كشف ذلك إلا لضرورة، أو لحاجة، كالشهادة عليها، أو داء

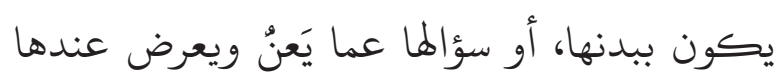
"Wanita itu seluruhnya adalah aurat, badannya maupun suaranya. Tidak boleh menampakkan

${ }^{23}$ Al-Mawsu'atul Fiqhiyyah al-Kuwaitiyyah, Kuwait-Wizaratul Awqaf wa al-Syu'un al-Islamiyyah, juz, XII, h. 134. 
wajahnya kecuali darurat atau ada kebutuhan mendesak seperti persaksian atau pengobatan pada badannya, atau kita dipertanyakan apakah ia adalah orang yang dimaksud (dalam sebuah persoalan)" 24

Al-Qurthubi berkata:

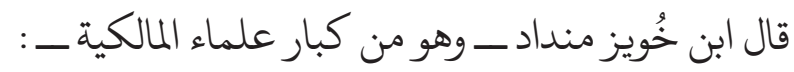

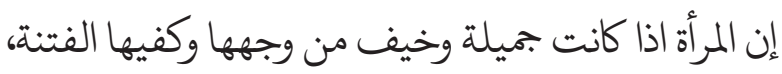

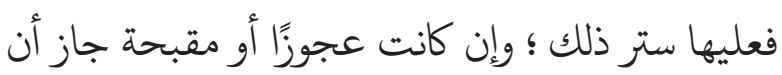

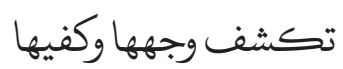

"Ibnu Juwaiz Mandad--ia adalah ulama besar Maliki--berkata: Jika seorang wanita itu cantik dan khawatir wajahnya dan telapak tangannya menimbulkan fitnah, hendaknya ia menutup wajahnya. Jika ia wanita tua atau wajahnya jelek, boleh baginya menampakkan wajahnya" ${ }^{25}$

Al-Zarqani berkata:

وعورة الحرة مع رجل أجنبي مسلم غير الوجه والكفين

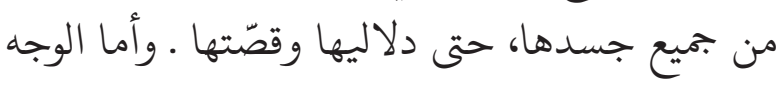

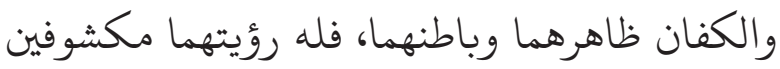

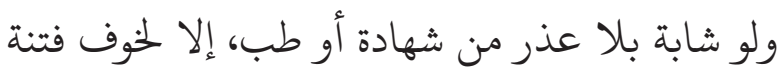

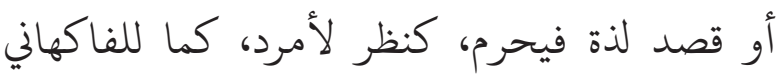
والقلشاني

"Aurat wanita di depan lelaki muslim ajnabi adalah seluruh tubuh selain wajah dan telapak tangan. Bahkan suara indahnya juga aurat. Sedangkan wajah, telapak tangan luar dan dalam, boleh dinampakkan dan dilihat oleh laki-laki walaupun wanita tersebut masih muda, baik sekedar melihat ataupun untuk tujuan pengobatan. Kecuali jika khawatir timbul fitnah atau lelaki melihat wanita untuk bersenang-senang, maka hukumnya haram, sebagaimana haramnya melihat amrâd. ${ }^{26}$

Al-Banani menjelaskan pendapat Al-Zarqani di atas:

$$
\begin{aligned}
& \text { وهو الذي لابن مرزوق في اغتنام الفرصة قائلًا: إنه }
\end{aligned}
$$

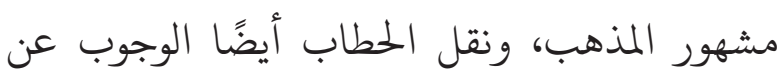

${ }^{24}$ Ibn al-`Arabi, Ahkâm al-Qur'ân, (Beirut: Dar al-Kutub, 2008), Juz 3, h. 1579.

${ }^{25}$ Qurthubi, al-Jâmi' li Ahkâm al-Qur'ân, Juz XII, h. 229.

${ }^{26}$ Muhammad Abd al-Baqiy bin Yusuf bin Ahmad bin Syihab al-Din bin Muhammad al-Zarqaniy Syarh al-Zarqani 'ala Muwattha' Imam Malik, (Beirut: Dar al-Ma`rifah, 1978), Jilid IV, h. 437.

$$
\begin{aligned}
& \text { القاضي عبد الوهاب، أو لا يجب عليها ذلك، وإنما } \\
& \text { على الرجل غض بصره، وهو مقتضى نقل مَوَّاق عن } \\
& \text { عياض • وفصّل الشيخ زروق في شرح الوغليسية بين }
\end{aligned}
$$

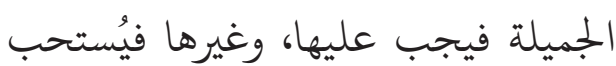

"Pendapat tersebut juga dikatakan oleh Ibnu Marzuq dalam kitab Ightimam al-Furshah, ia berkata: 'Inilah pendapat yang masyhur dalam madzhab Maliki'. Al-Hathab juga menukil perkataan al-Qadhi Abdul Wahhab bahwa hukumnya wajib. Sebagian ulama Maliki menyebutkan bahwa hukumnya tidak wajib, namun laki-laki wajib menundukkan pandangannya. Pendapat ini dinukil Mawwaq dari lyadh. Syaikh Zarruq dalam kitab Syarh al-Waghlisiyyah merinci, jika cantik maka wajib, jika tidak cantik maka sunah" ${ }^{27}$

Senada dengan pendapat di atas, al-Dardiri juga berpendapat:

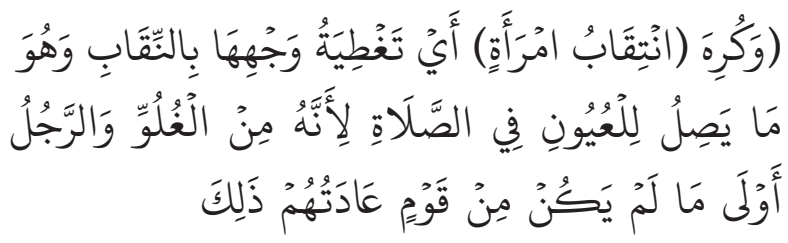

"Makruh bagi seorang perempuan menutup wajahnya dengan niqab--sesuatu yang menutupi mata--saat melakukan salat, karena hal itu termasuk berlebih-lebihan (ghuluw)--lebih-lebih bagi laki-laki. Kemakruhan ini berlaku selama penggunaan niqab bukan bagian dari adat atau tradisi setempat. ${ }^{28}$

Dengan demikian, mazhab Maliki membedakan hukum penggunaan cadar di luar salat dan di dalam salat. Untuk di luar salat, pada dasarnya wajah wanita bukanlah aurat, namun memakai cadar hukumnya sunah, dan bisa menjadi menjadi wajib jika dikhawatirkan menimbulkan fitnah. Sedangkan untuk di dalam salat, pemakaian cadar bagi wanita hukumnya makruh karena termasuk tindakan yang berlebihan.

Sedangkan di kalangan mazhab Syafi'i sendiri terjadi perbedaan pendapat. Pendapat pertama menyatakan bahwa memakai cadar hukumnya wajib bagi wanita. Pendapat kedua hukumnya adalah sunah, sedang pendapat ketiga

27 Al-`Allamah Al-Banani, Hâsyiyah al-`al-'Allâmah al-Banani 'ala Syarh al-Mahalli 'ala Syarh Jam 'al-Jawâmi', (Mesir: Musthafa al-Halabi, 1938), Juz I, h. 176.

28 Abi al-Barakat Ahmad Addardiri, Syarh al-Kabir 'ala Mukhtashar al-Khalil, (Mesir: Dar al-Ma`arif, t.th), Vol. I, h. 218. 
adalah menyalahi yang utama karena utamanya tidak bercadar (khilâf al-awlâ) ${ }^{29}$.

Dari tiga pendapat di atas, pendapat yang terkuat dan terpilih dalam mazhab Syafi'i adalah bahwa aurat perempuan dalam konteks yang berkaitan dengan pandangan pihak lain (al-ajânib) adalah semua badannya termasuk kedua telapak tangan dan wajah. Konsekuensinya adalah ia wajib menutupi kedua telapak tangan dan memakai cadar untuk menutupi wajahnya. Selain itu, dijelaskan pula:

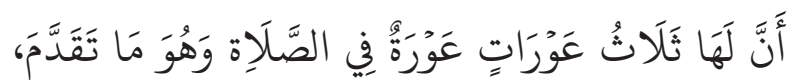

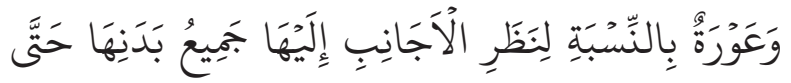

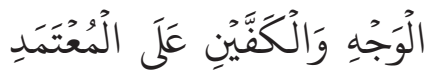

"Bahwa perempuan memiliki tiga aurat. Pertama, aurat dalam salat dan hal ini telah dijelaskan. Kedua aurat yang terkait dengan pandangan orang lain kepadanya, yaitu seluruh badannya termasuk wajah dan kedua telapak tangannya menurut pendapat yang mu'tamad..." 30

Oleh sebab itu, dalam mazhab Syafi'i, aurat wanita di depan lelaki ajnabi (bukan mahram) adalah seluruh tubuh. Sehingga mereka mewajibkan wanita memakai cadar di hadapan lelaki asing. Inilah pendapat mu'tamad dalam mazhab Syafi'i. Ini tampak dari penjelasan al-Syarwani:

إن لما ثلاث عورات: عورة في الصلاة، وهو ما تقدم -

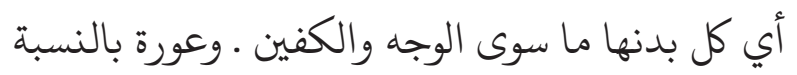

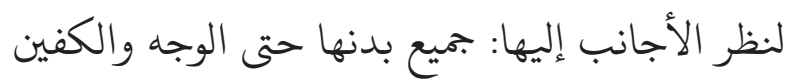

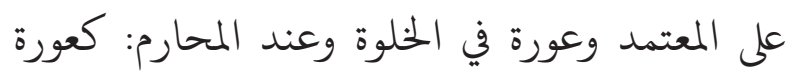

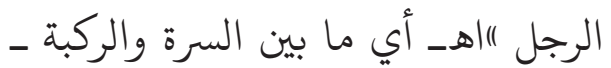

"Wanita memiliki tiga jenis aurat: pertama, aurat dalam salat--sebagaimana telah dijelaskan yaitu seluruh badan kecuali wajah dan telapak tangan; kedua, aurat terhadap pandangan lelaki ajnabi, yaitu seluruh tubuh termasuk wajah dan telapak tangan, menurut pendapat yang mu'tamad; ketiga, aurat ketika berdua bersama yang mahram, sama seperti laki-laki, yaitu antara pusat dan paha" ${ }^{31}$

${ }^{29}$ Al-Mawsu'atul Fiqhiyyah al-Kuwaitiyyah, (Kuwait-Wizaratul Awqaf was Syu'unul Islamiyyah, t. th), juz, XLI, h. 134.

${ }^{30}$ Abdul Hamid al-Syarwani, Hâsyiah al-Syarwani 'Ala Tuhfatul Muhtâj, (Maktabah al-Tijariyah Kubra, t. th), Juz II, h. 112.

${ }^{31}$ Abdul Hamid al-Syarwani, Hâsyiyah al-Syarwani..., Juz II, h. 113
Lalu ditambahkan oleh Sulaiman al-Jamal dengan mengatakan:

$$
\begin{aligned}
& \text { غير وجه وكفين: وهذه عورتها في الصلاة. وأما عورتها }
\end{aligned}
$$

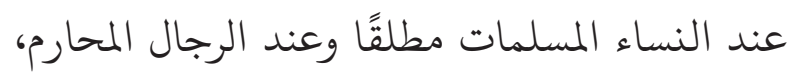

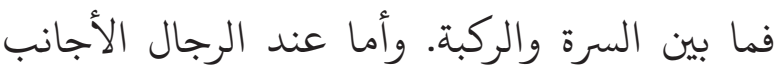

$$
\begin{aligned}
& \text { فجميح البدن }
\end{aligned}
$$

"(Aurat wanita adalah) selain wajah dan telapak tangan', ini adalah aurat di dalam salat. Adapun aurat wanita muslimah secara mutlak di hadapan lelaki yang masih mahram adalah antara pusat hingga paha. Sedangkan di hadapan lelaki yang bukan mahram adalah seluruh badan"32

Kemudian ditegaskan lagi oleh Muhammad bin Qasim al-Ghazzi:

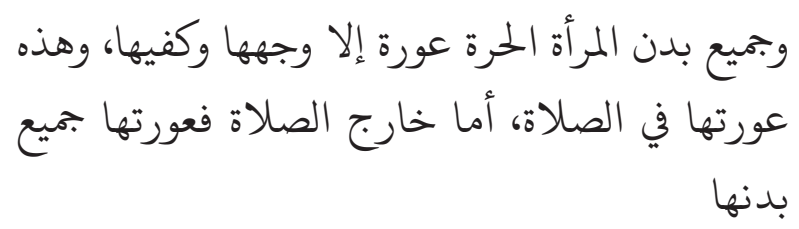

"Seluruh badan wanita kecuali wajah dan telapak tangan adalah aurat. Ini aurat di dalam salat. Adapun di luar shalat, aurat wanita adalah seluruh badan"33

Dan Ibnu Qasim al-Abadi menjelaskan alasan kewajiban tersebut dengan berkata:

$$
\text { ويجب ما ستر من الأنثى ولو رقيقة ما عدا الوجه }
$$

"Wajib bagi wanita menutup seluruh tubuh selain wajah telapak tangan, walaupun penutupnya tipis. Dan wajib pula menutup wajah dan telapak tangan, bukan karena keduanya adalah aurat, namun karena secara umum keduanya cenderung menimbulkan fitnah" 34

Selanjutnya Taqiyuddin al-Hushni merincinya dengan mengatakan:

ويُكره أن يصلي في ثوب فيه صورة وتمثيل، والمرأة

${ }^{32}$ Sulaiman ibn Umar ibn Mansur al-Ujaili al-Azhari alJamal, Futuhat al-Wahhab bi Taudhih Syarh Manhaj al-Thullâb (Hâsyiyatul Jamâl 'Ala' Syarh al-Minhâj), (Mesir: Dar Ihya alTurats al-Arabi, t. th), h. 411.

33 Syamsuddin Abu Abdillah Muhammad bin Qasim alSyafi'i, Fath al-Qarib, (Beirut: Dar al-Kutub al-Ilmiyah), t. th), h. 19.

${ }^{34}$ Ahmad ibn Qasim al-Ubadi, Hâsyiyah Ibnu Qasim 'Ala Tuhfatul Muhtâj, (Beirut: Dar al-Kutub al-Ilmiyah), t. th), Juz III, h. 115 . 


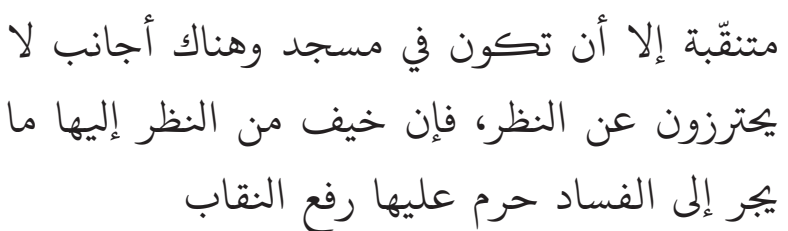

"Makruh hukumnya salat dengan memakai pakaian yang bergambar atau lukisan. Makruh pula wanita memakai cadar ketika salat. Kecuali jika di masjid kondisinya sulit terjaga dari pandangan lelaki asing. Jika wanita khawatir dipandang oleh lelaki asing sehingga menimbulkan kerusakan, hukumnya haram melepaskan cadar". 35

Dengan demikian, dalam mazhab Syafi i dibedakan antara aurat di dalam salat dan di luar salat. Untuk di luar salat, mereka sepakat wajib bagi muslimah untuk bercadar dengan alasan kekhawatiran menimbulkan fitnah, walaupun pada dasarnya wajah dan telapak tangan bukanlah termasuk aurat. Tetapi untuk di dalam salat, makruh hukumnya bagi muslimah untuk bercadar, kecuali jika di tempat ia salat ada laki-laki ajnabi yang dikhawatirkan berpotensi menimbulkan bahaya, maka dalam hal ini si muslimah tadi wajib menggunakan cadarnya.

Sedangkan dalam mazhab Hambali, Imam Ahmad bin Hambal berkata:

كل شيء منها - أي من المرأة الحرة - عورة حتى

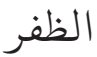

"Setiap bagian tubuh wanita adalah aurat-yaitu wanita merdeka--termasuk pula kukunya" 36

Dalam kitab al-Raudhul Murbi' disebutkan:

"ا وكل الحرة البالغة عورة حتى ذوائبها، صرح به في الرعاية ـ اهـإلا وجهها فليس عورة في الصلاة . وأما خارجها فكلها عورة حتى وجهها بالنسبة إلى الرجل والخنثى وبالنسبة إلى مثلها عورتها ما بين السرة إلى الركبة

"Setiap bagian tubuh wanita yang baligh adalah aurat, termasuk pula sudut kepalanya. Pendapat ini telah dijelaskan dalam kitab al-Ri âyah... kecuali wajah, karena wajah bukanlah aurat di

35 Taqiyyudin Abubakar bin Muhammad al-Husaini alDimasyqi, Kifayat al-Akhyâr fi Halli Ghâyat al-Ikhtishâr, (Damaskus: Dar al-Basya'ir, 2001), Cet. ke-9, h. 181.

${ }^{36}$ Abu al-Faraj al-Jauzi, Zâd al-Masir fi 'llm al-Tafsir, (Beirut: Dar Ibn Hazm, 2002), Cet. ke-1, Juz VI, h. 31. dalam salat. Adapun di luar salat, semua bagian tubuh adalah aurat, termasuk pula wajahnya jika di hadapan lelaki atau di hadapan banci. Jika di hadapan sesama wanita, auratnya antara pusat hingga paha"37

Hal ini ditegaskan lebih lanjut:

(وهما)" أي: الكفان . (والوجه)) من الحرة البالغة (اعورة

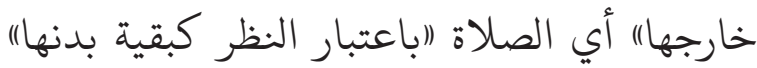
"Dan keduanya, yaitu dua telapak tangan dan wajah adalah aurat bagi wanita yang sudah baligh di luar salat, karena adanya pandangan dianggap sama seperti anggota badan lainnya"38

Bahkan Ibnu Muflih menambahkan:

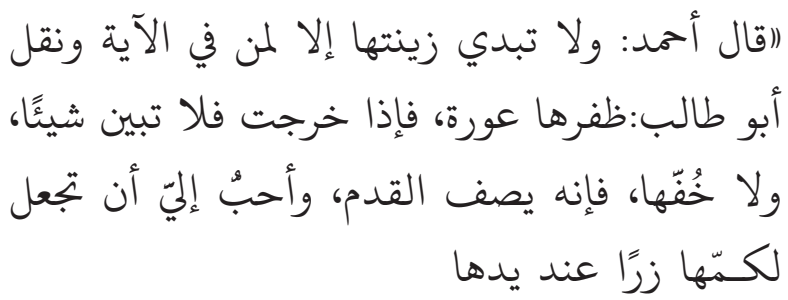

"Imam Ahmad berkata: 'Maksud ayat tersebut ialah janganlah mereka (wanita) menampakkan perhiasan mereka kecuali kepada orang yang disebutkan di dalam ayat'. Abu Thalib menukil penjelasan dari beliau (Imam Ahmad): 'Kuku wanita termasuk aurat, jika mereka keluar, tidak boleh menampakkan apa pun bahkan khuf (semacam kaus kaki), karena khuf itu masih menampakkan lekuk kaki. Dan aku lebih suka jika mereka membuat semacam kancing tekan di bagian tangan"39

Selanjutnya Muhammad bin Shalih Al-Utsaimin menegaskan bahwa:

$$
\text { القول الراجح في هذه المسألة وجوب ستر الوجه عن }
$$

"Pendapat yang kuat dalam masalah ini adalah wajib hukumnya bagi wanita untuk menutup wajah dari pada lelaki ajnabi" 40

Dengan demikian, menurut mazhab Hambali bahwa untuk di luar salat, seluruh tubuh wanita adalah aurat, sehingga wajib bagi wanita untuk

37 Syaikh Manshur bin Yunus al-Bahuti Al Mishri, AlRaudhu al-Murbi' Syarhu Zâd al-Mustaqni', (Mesir: Dar alHadits, t.th), h. 140.

${ }^{38}$ Al-Bahuti al-Mishri, Al-Raudhu al-Murbi'..., h. 309.

${ }^{39}$ Muhammad ibn Muflih al-Maqdisi, Al Furu', (Damaskus: Bait al-Afkar, t.th), h. 601-602.

40 Muhammad ibn Shalih Al-Utsaimin, Fatâwâ Nurun 'Ala al-Darb, Edisi CD Maktabah Syamilah 
menutupinya, termasuk dengan penggunaan cadar. Pengecualian hanya di dalam salat yaitu khusus wajah yang tidak termasuk aurat, sehingga hukumnya mubah untuk tidak ditutupi.

\section{Fenomena Pro Kontra Penggunaan Cadar di Perguruan Tinggi}

Seiring dengan maraknya kajian-kajian keislaman di era keterbukaan kini, ditambah sarana media elektronik via internet, menjadikan setiap orang sangat mudah mempelajari Islam secara mandiri. Dan kampus menjadi salah satu tempat yang strategis untuk mendiskusikannya dan lahan subur untuk mengembangkan paham keislaman dari berbagai aliran yang ada.

Dalam konteks sosial, keberadaan perempuan bercadar masih belum dapat diterima secara penuh oleh masyarakat. Terdapat persepsi sosial yang negatif terhadap prilaku bercadar yang mereka lakukan. Penggunaan cadar yang dilakukan oleh kaum perempuan tersebut dianggap mengganggu proses hubungan antar pribadi dalam bermasyarakat. Ada anggapan bahwa penggunaan cadar sebagai hambatan untuk menciptakan keadaan yang lebih baik, dimana hubungan positif di antara masyarakat semakin sulit, karena melihat wajah adalah sesuatu yang fundamental dalam hubungan antar sesama. ${ }^{41}$

Terkait penggunaan cadar di perguruan tinggi, Guru Besar Fakultas Syariah dan Hukum Universitas Islam Negeri Sunan Gunung Djati Bandung, Mohammad Najib mengatakan bahwa aturan larangan bercadar bertentangan dengan fungsi Perguruan Tinggi. Menurutnya, dalam Undang Undang tentang Pendidikan Tinggi disebutkan bahwa Perguruan Tinggi dalam menjalankan tugas dan fungsi akademik memiliki otoritas kebebasan akademik dan kebebasan mimbar akademik. Kebebasan akademik tersebut menyangkut kebebasan Perguruan Tinggi mengembangkan keilmuan yang betsifat akademik. Maka, menurutnya jika seseorang punya pandangan dan pemikiran akademik bahwa bercadar itu bagian dari pemahaman

${ }^{41}$ Bakar bin Abdullah Abu Zaid, Menjaga Kehormatan, (Jakarta: al-Safwa, 2013), h. 65. dan interpretasi akademik terhadap teks ajaran agama, kemudian diekspresikan dalam prilakunya, sepanjang dia memiliki landasan kerangka pikir dan metodologi akademis, maka itu sah sah saja secara akademik. Dengan demikian, kebebasan akademik menyangkut kebebasan para civitas akademik dalam mengekspresikan pikiran, pandangan, pendapat, ide, hasil penelitian, mengembangkan ilmu berdasarkan kerangka pikir yang bisa dipertanggungjawabkan secara akademik. ${ }^{42}$

Dewan Tertinggi Al-Azhar telah mengeluarkan qarar (keputusan) yang diketuai langsung Imam Besar, Muhammad Sayyid Thantawi. Qarar tersebut berisi larangan pemakaian cadar bagi semua wanita di lingkungan sekolah dan kuliah banât Al-Azhar. Muhammad Abdul Mun`im al-Bary, Guru Besar Universitas Al-Azhar dan mantan sekretaris jendral Jabhah Ulama AlAzhar mengatakan bahwa cadar bukanlah suatu kewajiban, namun suatu keutamaan (fadhilah). Menurutnya, tidak ada dalil dalam Alquran dan sunah yang menegaskan kewajiban cadar, berbeda dengan jilbab (hijab) yang jelas diwajibkan dalam Alquran dan sunah. Oleh sebab itu, pihak kampus memaksa para mahasiswi untuk melepaskan cadar mereka ketika masuk ke ruang ujian, atau mereka sama sekali tidak boleh masuk dan mengikuti ujian semester. Pejabat Universitas Kairo menyatakan bahwa keputusan harus melepas cadar selama ujian berlangsung atau sewaktu masuk ke ruang ujian telah menjadi keputusan pimpinan universitas, dan para mahasiswi yang bercadar tidak boleh menolak keputusan tersebut. Bagi mahasiswi yang tetap tidak mau melepaskan cadarnya, mereka akan dianggap gagal dalam ujian semester. ${ }^{43}$

Dalam konteks Indonesia, kondisi yang berkembang saat ini juga menempatkan perempuan pengguna cadar lekat dengan stigma teroris ataupun gerakan-gerakan Islam radikal. Fenomena radikalisme keagamaan yang pernah

42 https://jurnalislam.com/guru-besar-uin-bandunglarangan-cadar-bertentangan-dengan-fungsi-perguruantinggi/ diakses tanggal 21 Maret 2018

43 Era Muslim, Ulama Mesir Mendukung Larangan Cadar di Mesir, dikutip dari https://www.eramuslim.com/berita/duniaislam/pelarangan-cadar-di-mesir-didukung-ulama-terkemuka. htm\#, diakses tanggal 29 Februari 2018 
terjadi seperti teror peledakan di Indonesia yang melibatkan nama seperti Amrozi, Imam Samudera, dan Ali Imron, kerap menyisakan sosok perempuan bercadar di balik mereka. Dengan alasan inilah, kemudian sebagian masyarakat mengasosiasikan keberadaan setiap perempuan bercadar dekat dengan teroris, Islam garis keras, dan Islam fanatik. ${ }^{4}$

Oleh sebab itu, eksklusifitas dan ketertutupan komunitas cadar dapat menghambat proses sosialisasi. Ditambah lagi masyarakat Indonesia yang serba ingin tahu dari pola kecendrungan masyarakat kolektif, tentu melihat hal-hal yang serba tertutup membuat mereka enggan untuk berinteraksi lebih jauh. Karena opini masyarakat umum adalah cadar belum menjadi budaya muslim Indonesia.

Dari pro kontra yang terjadi sekitar larangan bercadar di perguruan tinggi, maka dapat disederhanakan antara kelompok yang menentang larangan tersebut dan yang menerimanya sebagai berikut:

1. Bagi kelompok yang setuju terhadap larangan tersebut beralasan bahwa pertama, mengganggu proses interaksi antar pribadi di masyarakat, sehingga terkesan eksklusif. Kedua, menyulitkan proses pembelajaran, baik si wanita sebagai mahasiswi yang harus terpantau perkembangannya oleh dosen, maupun jika wanita tersebut adalah dosen di perguruan tinggi. Ini bisa menimbulkan gap atau kecanggungan yang dapat mempengaruhi kurang maksimalnya implementasi sistem perkuliahan. Ketiga, dapat berpotensi munculnya kecurangan dalam ujian masuk, ujian semester, dan ujian lainnya yang menjadi bagian proses akademik di kampus. Sebab bisa saja misalnya, seorang wanita mewakilkan dirinya pada saat ujianujian tersebut pada joki bayaran. Keempat, dapat menimbulkan bahaya bagi wanita ketika yang bersangkutan pergi ke tempattempat tertentu yang sepi atau tertutup seperti toilet, ruang khusus wanita atau lainnya yang rentan terhadap laki-laki yang

${ }^{44}$ Lintang Ratri, “Cadar, Media, dan Identitas Perempuan Muslim”, Jurnal Forum,Universitas Diponegoro Semarang, Vol. 39, No. 2, 2017, h. 33. menyamar sebagai wanita. Kelima, ada stigma cadar adalah identik dengan pakaian istri teroris. Sebab faktanya di Indonesia, istriistri teroris yang tertangkap atau terbunuh, semuanya menggunakan cadar. Keenam, bagi mahasiswi yang kuliah di fakultas kedokteran, ketika praktek misalnya, akan membuat pasien ragu karena tidak tahu persis siapa perawat atau dokter yang menanganinya. Dan bagi keluarga pasien juga akan menyulitkan mengenalinya jika suatu saat melakukan malpraktek, sehingga menimbulkan kecurigaan. Ketujuh, pada kasus mahasiswi yang ingin menikah, ini tentu menyulitkan bagi calon suaminya untuk mengenal yang bersangkutan. Dikhawatirkan akan menimbulkan penyesalan di kemudian hari setelah menikah karena tidak sesuai dengan harapannya. Oleh sebab itu, tentu sulit menciptakan keluarga sakinah.

2. Bagi yang menolak larangan pemakaian cadar di perguruan tinggi beralasan pertama, bercadar merupakan bagaian dari implementasi perintah agama. Ini tentunya bagi yang berpaham bahwa cadar itu sama dengan khimar atau jilbab. Sehingga jika tidak dilaksanakan berakibat pada dosa. Kedua, menghindari fitnah. Mereka merujuk pada pendapat dalam mazhab Hambali yang menganggap bahwa aurat wanita itu adalah seluruh bagian tubuh wanita kecuali mata. Oleh sebab itu, wajah termasuk aurat yang tidak boleh dilihat kecuali oleh orang yang semahram dengan wanita tersebut. Jika tidak ditutupi dan terlihat oleh laki-laki lain yang bukan mahramnya, dikhawatirkan berpotensi menimbulkan fitnah. Ketiga, untuk menjaga prilaku mahasiswi, khususnya bagi mahasiswi penghafal Alquran diyakini akan lebih memudahkannya menghindari kontak langsung dengan laki-laki lain yang tidak memiliki keperluan mendesak.

\section{Eksistensi Sadd al-Dzarî̀ah sebagai Dalil Hukum}

Secara bahasa, kata al-dzarîah berarti sarana. Sedang menurut istilah Ushûl al-Fiqh ialah sarana atau jalan untuk sampai pada tujuan. Dan tujuan yang dimaksud ada kalanya perbuatan-perbuatan 
taat, dan ada kalanya pula perbuatan-perbuatan maksiat. Perbuatan taat berarti mashlahah, sedang perbuatan maksiat berarti mafsadah. Sesuatu yang menjadi sarana kepada yang diharamkan (membawa mafsadah/kerusakan), maka sarana tersebut harus ditutup dan dicegah, dan inilah yang disebut dengan sadd al-dzarî̀ah. Tapi jika sarana itu membawa pada perbuatan-perbuatan taat atau mengandung kemaslahatan, maka harus dibuka peluang untuk melaksanakannya, biasa disebut dengan fathu al-dzarîah. ${ }^{45}$ Imam Malik dan Ahmad bin Hambal menempatkan sadd al-dzarîah sebagai salah satu dalil hukum. Sedangkan Abu Hanifah dan mazhab Syiah menerapkan sadd aldzarîah pada kondisi tertentu. Adapun mazhab Zhahiri menolak penggunaannya secara total. ${ }^{46}$ Bagi yang menerima sadd al-dzarîah sebagai dalil hukum, beralasan dengan Alquran surat al-An`am(6) ayat 108 dan hadis Nabi saw: "Ketahuilah, sesungguhnya larangan-larangan Allah ialah maksiat (terhadap) Nya. Siapa yang berkeliling di sekitar larangan, diragukan ia akan jatuh kepadanya". (HR. Muslim). Hadis tersebut diperkuat dengan hadis lain: "Tinggalkanlah apa yang engkau ragukan kepada apa yang tidak engkau ragukan". (HR. Tirmidzi) ${ }^{47}$

Jadi dzarîah adalah sarana dan jalan yang menyampaikan kepada tujuan, baik yang halal ataupun yang haram. Dalam hukum taklifi, telah dijelaskan tentang sesuatu yang mendahului perbuatan wajib, disebut dengan muqaddimah wajib. Karena muqaddimah merupakan washîlah (perantara) kepada suatu yang dikenai hukum, maka ia juga disebut dzarî'ah. Oleh sebab itu, para penulis dan ulama usul fikih memasukkan muqaddimah wajib kedalam pembahasan tentang dzarîah, karena sama-sama sebagai perantara untuk melakukan sesuatu. Setiap perbuatan mengandung dua sisi, pertama adalah sisi yang mendorong untuk berbuat, kedua adalah sasaran atau tujuan yang menjadi natîjah (kesimpulan/ akibat) dari perbuatan itu. Menurut natîjahnya, perbuatan itu ada 2 bentuk: pertama, jika

45 Wahbah al-Zuhaili, al-Wasîth fi Ushûl al-Fiqh al-Islâmi, (Damaskus: Dâr al-Kitâb, 1978), h. 873-874.

${ }^{46}$ Wahbah al-Zuhaili, Ushûl al-Fiqh al-Islâmi, (Damsyiq: Dar al-Fikr, 1986), Juz II, h. 888.

47 Muhammad ibn Isa Abu Isa al-Tirmidzi, Sunan alTirmidzî, (Beirut: Dar Ihya al-Turâts al-`Arabi, t.th), Juz IV, h. 77. natîjahnya baik, maka segala sesuatu yang mengarah kepadanya adalah baik dan karena itu dituntut untuk mengerjakannya. Kedua, jika natîjahnya buruk, maka segala sesuatu yang mendorong kepadanya adalah juga buruk, dan karena itu dilarang. Untuk menetapkan hukum jalan (sarana) yang mengharamkan kepada tujuan, dalam sadd al-zarîah terdapat tiga hal yang perlu dipehatikan. Pertama, menyangkut tujuan. Jika tujuannya dilarang, maka jalannya pun dilarang dan jika tujuannya wajib, maka jalannya pun diwajibkan. Kedua, menyangkut niat (motif). Jika niatnya untuk mencapai yang halal, maka hukum sarananya halal, dan jika niat yang ingin dicapai haram, maka sarananya pun haram. Ketiga, menyangkut akibat dari dari suatu perbuatan. ${ }^{48}$

Pada dasarnya, tidak ada dalil yang jelas dan pasti baik dalam bentuk nas maupun ijma` ulama tentang boleh atau tidaknya menggunakan sadd al-dzarîah sebagai dalil hukum. Oleh sebab itu, dasar pengambilannya semata-mata ijtihad ulama yang berdasarkan pada tindakan hati-hati dalam mengantisipasi dan jangan sampai melakukan perbuatan yang dapat menimbulkan kerusakan. Adapun yang dijadikan pedoman dalam tindakan hati-hati tersebut adalah faktor manfaat dan mudharat yang diakibatkannya. Dan jumhur ulama yang selalu menempatkan faktor manfaat dan mudharat sebagai bahan pertimbangan hukum, pada prinsipnya juga menerima metode sadd aldzarîah sebagai dalil hukum, meskipun berbeda dalam kadar penerimaannya.

Ditetapkannya sadd al-dzarîah sebagai salah satu dalil hukum mengandung makna bahwa walaupun syara` tidak menetapkan hukum suatu perbuatan secara jelas, namun karena perbuatan itu diyakini sebagai washîlah bagi perbuatan yang dilarang atau menimbulkan mafsadat, maka hal itu menjadi petunjuk bahwa hukum washîlah itu adalah seperti hukum terhadap perbuatan atau akibat yang ditimbulkannya. Ada perbuatan yang sebenarnya hukumnya mubah, tapi jika berpotensi menimbulkan bahaya, maka perbuatan tersebut menjadi dilarang. Misalnya menghentakkan kaki

48 Muaidi, "Sadd al-Dzariah dalam Hukum Islam", Tafaqquh: Jurnal Hukum Ekonomi Syariah dan Ahwal Syakhsiyah, Vol. 1, No. 2, Desember 2016, h. 2. 
pada dasarnya boleh bagi laki-laki dan perempuan. Tapi bagi perempuan jika menghentakkan kakinya akan menyebabkan perhiasannya yang tersembunyi dapat diketahui laki-laki lain sehingga akan menimbulkan rangsangan bagi yang mendengarnya, maka menghentakkan kaki itu menjadi terlarang bagi perempuan. Ini dijelaskan dalam al-Nur[24] ayat 31.

Terkait dengan implementasi sadd al-dzarîah, Abu Ishaq al-Syatibi membagi dzarîa menjadi 4 macam. ${ }^{49}$ Pertama, dzarîah yang membawa kerusakan secara pasti. Artinya jika perbuatan itu tidak dihindarkan, pasti akan terjadi kerusakan. Misalnya menggali lobang pada waktu gelap di tanah sendiri tapi dekat dengan pintu rumah orang lain, sehingga orang yang keluar dari rumah itu pasti akan jatuh ke dalam lobang tersebut. Kedua, dzarîah yang membawa kepada kerusakan menurut biasanya. Artinya kalau perbuatan itu dilakukan, maka kemungkinan besar akan timbul kerusakan atau dilakukannya perbuatan yang dilarang. Misalnya menjual anggur kepada pabrik pengolahan minuman keras atau menjual pisau kepada penjahat yang sedang mencari musuhnya. Ketiga, dzarîah yang membawa kepada perbuatan yang terlarang menurut kebanyakannya. Artinya jika perbuatan itu dilakukan, tidak terhindarkan seringkali sesudah itu akan mengakibatkan terjadinya perbuatan yang terlarang. Misalnya jual beli kredit. Walaupun tidak selalu jual beli kredit itu membawa pada riba, namun dalam prakteknya sering dijadikan sarana untuk riba. Keempat, dzarîah yang jarang sekali membawa pada kerusakan atau perbuatan yang dilarang. Artinya jika perbuatan itu dilakukan, belum tentu akan menimbulkan kerusakan. Misalnya menggali lobang di kebun sendiri yang jauh dari perumahan penduduk, namun tidak tertutup kemungkinan ada orang yang nyasar lalu jatuh ke dalam lobang tersebut.

Dari segi akibat (dampak) yang ditimbulkannya, Ibnu Qayyim--sebagaimana dikutip Amir Syarifuddin--membagi dzarîah menjadi 4 yaitu: pertama, dzarîah yang pada dasarnya membawa kepada kerusakan, seperti meminum minuman

${ }^{49}$ Abu Ishaq al-Syatibi, al-Muwâfaqât fi Ushûl al-Syarî’ah, disunting oleh Abdullah Darrâz, (Mesir: Maktabah al-Tijariyah al-Kubra, t. th)., Juz IV, h. 198. yang memabukkan akan merusak akal dan perbuatan zina akan merusak keturunan. Kedua, dzarîah yang ditentukan untuk sesuatu yang mubah (boleh), namun ditujukan untuk perbuatan buruk yang merusak, baik yang disengaja seperti nikah muhallil atau tidak disengaja seperti mencaci sesembahan agama lain. Ketiga, dzarîah yang semula ditentukan mubah, tidak ditujukan untuk kerusakan, namun biasanya sampai juga kepada kerusakan dan kerusakan itu lebih besar daripada kebaikannya. Misalnya seorang istri yang berhias padahal ia baru kematian suami dalam masa iddah. Keempat, dzarîah yang semula ditentukan mubah, namun terkadang membawa kepada kerusakan tetapi kerusakannya lebih kecil daripada kebaikannya. Misalnya melihat wajah perempuan saat dipinang. ${ }^{50}$

Menurut Ibrahim Hosen, intisari dari sadd al-dzarîah adalah menutup jalan yang menuju kepada yang haram/dilarang oleh Islam sebagai tindakan preventif. ${ }^{51}$ Dalam penerapan sadd al-dzarîah ini, mengkhususkan kepada sarana yang dapat membawa manusia kepada maksiat/ haram. Dengan demikian, walaupun pada mulanya sarana itu sendiri hukumnya mubah, tetapi karena sarana itu akan membawa ke arah maksiat/haram, maka sarana itupun diharamkan. Hal ini sejalan dengan kaedah "li al-wasâ'il hukm al-maqâsid." Oleh sebab itu, haramnya disebut harâm li sadd al-zarîâh. Para ulama terdahulu biasa memberi contoh dengan haramnya melihat aurat, baik laki-laki melihat aurat wanita maupun sebaliknya. Melihat aurat tersebut diharamkan karena hal itu dapat menjadi sarana ke arah perbuatan zina. Jadi 'illat haramnya bukanlah karena laki-laki atau wanitanya, tetapi demi keamanan. ${ }^{52}$

Dalam rangka usaha pembaruan pemikiran hukum Islam di era kontemporer, maka dalil sadd al-dzarîah ini harus selalu dijadikan pertimbangan dan disosialisasikan lebih luas intensitas penggunaannya. Sebab dengan sadd aldzarîah ini dapat juga diterapkan terhadap segala sesuatu yang dianggap dapat membahayakan

50 Amir Syarifuddin, Ushul Fiqh, (Jakarta: Logos Wacana Ilmu, 2013), Cet. ke-11, Jilid I, h. 402.

${ }^{51}$ Ibrahim Hosen, Beberapa Catatan, h. 271

${ }^{2}$ Toha Andiko, "Reinterpretasi Sanksi Pidana Islam (Studi terhadap Pemikiran Prof. KH. Ibrahim Hosen, LML", Jurnal Madania, Vol. XVIII, No. 2, Desember 2014, h. 239 
agama dan masyarakat banyak secara umum. Sebagai contoh, diharamkannya perkawinan beda agama yang dikhawatirkan dapat merusak akidah istri atau anak-anaknya kelak. Dan dengan dalil ini pun dapat digunakan pemerintah untuk melarang penjualan bebas alat kontrasepsi untuk menghindari terjadinya penyalahgunaan, peredaran buku porno, film cabul, poster film yang tidak sopan, penutupan panti pijat yang pekerjanya wanita berpakaian minim, bank sperma, dan bayi tabung dari suami istri yang normal, termasuk bayi tabung dari sperma suami yang telah meninggal untuk mencegah terjadinya penyalahgunaan oleh orang-orang yang tidak bertanggung jawab dengan motif-motif tertentu. ${ }^{53}$

Pada prinsipnya, sadd al-dzarîah adalah sebagai upaya mujtahid untuk menetapkan larangan pada suatu kasus yang pada dasarnya hukum asalnya adalah mubah. Larangan ini dimaksudkan untuk menghindari suatu perbuatan atau akibat lain yang mengandung bahaya, kerusakan, dan kejahatan. Oleh sebab itu, metode ini lebih bersifat preventif dan antisipatif. ${ }^{54}$

\section{Tinjauan Sadd al-Dzarî̀ah terhadap Larangan Penggunaan Cadar di Perguruan Tinggi}

Latar belakang munculnya gagasan melarang cadar di kampus, bermula dari Sebuah foto bergambar mahasiswi bercadar di dekat Masjid Kampus Universitas Islam Negeri Sunan Kalijaga (UIN) Yogyakarta yang membuat resah jajaran otoritas kampus setempat. Di dalam foto itu, sejumlah orang terlihat memegang bendera organisasi yang dilarang pemerintah, Hizbut Tahrir Indonesia ( $\mathrm{HTI})$. Foto tersebut beredar di media sosial pada awal 2018 dan kemudian membuat kampus setempat bergerak. Adanya dugaan UIN Sunan Kalijaga disusupi gerakan radikal, menyebabkan jajaran rektorat mengeluarkan surat soal kebijakan mendata dan akan membina mahasiswi bercadar. ${ }^{55}$ Surat bernomor B-1031/

53 Ibrahim Hosen, "Peranan Lembaga ljtihad Dalam Pengembangan Hukum Islam", Makalah disampaikan pada Halaqah Ilmiah Alumni Timur Tengah, Jakarta, 28 Mei 1989, h. 13.

${ }_{54}$ Moh. Mahrus, "Aplikasi Al-Dzari'ah dan al-Halah Perspektif Hukum Islam", Jurnal Hukum Islam IAIN Pekalongan, Oktober 2009, h. 4.

55 http://jateng.metrotvnews.com/peristiwa/Rb1ZdRYk-
Un.02/R/AK.00.3/02/2018 ini ditandatangani oleh Rektor UIN Sunan Kalijaga, Yudian Wahyudi.

Ternyata, larangan bercadar yang seperti ini sudah diterapkan di perguruan tinggi Islam lainnya di Mesir, tapi sifatnya terbatas. Syekh Sa'd AlAlfi, penasihat salah satu Ma'ahid Al-Azhar dan kepala Ma'had Al-Qur'an Al-Karim Al-Azhari, justru memandang positif keputusan Dewan tertinggi Al-Azhar yang terkait dengan cadar. "Ada sebab yang kuat yang melatarbelakangi dikeluarkan keputusan tersebut dan ini tidak bertentangan dengan syariat Islam. Keputusan ini berdasarkan atas tidak adanya kewajiban bercadar dalam Islam. Oleh sebab itu, merupakan hak Al-Azhar untuk mengeluarkan peraturan yang dianggap selaras dengan kemaslahatan," tegas Al-Alfi. "Lagi pula larangan tersebut hanya di tempattempat tertentu, yaitu tempat-tempat khusus wanita. Jadi, selama tujuan pengunaan cadar oleh wanita adalah kekhawatiran jika wajahnya terlihat oleh laki-laki, maka larangan Al-Azhar tersebut tidak termasuk sebagai pelanggaran terhadap hak wanita," kata Al-Alfi. la juga menambahakan, larangan Al-Azhar tersebut bertujuan untuk memberikan perlindungan bagi mereka dari laki-laki tak bertanggung jawab yang menerobos masuk ke lingkungan sekolah, kampus, atau bahkan asrama putri dengan menutupi identitasnya melalui cadar.

Larangan bercadar ini juga diberlakukan oleh perguruan tinggi umum di Indonesia seperti pada Universitas Sumatera Utara (USU), khususnya pada fakultas Kedokteran. Di sini ditetapkan larangan bagi mahasiswi yang berbusana muslim dengan cadar. Alasannya pengelola fakultas khawatir jika mahasiswi tersebut bercadar, dapat memalsukan identitas saat mengikuti ujian atau praktikum. Selain itu, cadar dianggap bisa menyebabkan pasien yang mereka tangani menjadi risih. Bahkan pihak fakultas meng ultimatum mahasiswi yang tetap bercadar agar pindah ke kampus lain. ${ }^{56}$

Pada dasarnya, semua ulama fikih dari berbagai mazhab telah sepakat tentang hukum

\footnotetext{
larangan-cadar-bermula-dari-foto-hti-di-kampus, diakses tgl 5 April 2018

${ }^{56}$ Tempo, Gelar atau Cadar?, dikutip dari https://majalah. tempo.co/read/77163/gelar-atau-cadar, diakses 21 Februari 2018.
} 
wajibnya menutup aurat bagi wanita, baik dengan jilbab maupun khimar. Ini berdasarkan dalil yang bersumber dari Alquran dan hadis secara langsung. Sementara penutupan aurat dengan keharusan menggunakan cadar (niqab), tidak ditemukan dalilnya yang qath 'i, kecuali untuk istriistri Nabi Muhammad saw sebagai pengkhususan. Oleh sebab itu, pemakaian cadar bagi muslimah sebenarnya tidak wajib, tapi hanya disunahkan, itu pun bagi muslimah yang berwajah cantik jika dikhawatirkan menimbulkan fitnah.

Dalam tinjauan sadd al-dzarîah, untuk menetapkan hukum jalan (sarana) yang mengharamkan kepada tujuan, terdapat tiga hal yang perlu diperhatikan. Pertama, menyangkut tujuan. Jika tujuannya dilarang, maka jalannya pun dilarang dan jika tujuannya wajib, maka jalannya pun diwajibkan. Dalam kaitannya dengan cadar, pada prinsipnya ulama sepakat tidak ada yang mewajibkan ataupun melarang pemakaian cadar bagi muslimah. Paling tinggi ada pendapat yang menganggap hukumnya sunah atau lebih utama dan bisa menjadi wajib, itupun dengan pertimbangan jika muslimah itu cantik dan dikhawatirkan menimbulkan potensi bahaya pelecehan oleh laki-laki lain terhadap muslimah tersebut. Jadi penggunaan cadar di sini lebih sebagai usaha preventif dan antisipatif. Jika ini tujuan utamanya, maka jika tujuan tersebut sudah bisa diatasi dengan sistem pengamanan dan aturan yang jelas lagi rinci di perguruan tinggi, tentu hukum bercadar kembali pada hukum asalnya adalah mubah.

Kedua, menyangkut niat (motif). Jika niatnya untuk mencapai yang halal, maka hukum sarananya halal, dan jika niat yang ingin dicapai haram, maka sarananya pun haram. Terkait dengan motif bercadar, bagi yang beralasan bahwa bercadar merupakan bagian dari implementasi perintah agama dan menganggap bahwa cadar itu sama dengan kewajiban menggunakan khimar atau jilbab, sehingga jika tidak dilaksanakan berakibat pada dosa, tentu pemahaman ini perlu diluruskan. Sebab dari segi bahasa dan tinjauan sejarah, antara khimar, jilbab, dan cadar (niqab), makna dan prakteknya juga berbeda. Sedang bagi yang beralasan dengan motif menghindari fitnah dan merujuk pada pendapat dalam mazhab Hambali yang menganggap bahwa aurat wanita itu adalah seluruh bagian tubuh wanita kecuali mata, ini pun terbantahkan karena pada dasarnya ini pendapat minoritas. Dibandingkan dengan pendapat jumhur (mazhab Hanafi, Maliki, Syafii), maka masalah batasan aurat wanita termasuk masalah khilafiyah. Memang karena masalah ini termasuk masalah ijtihadiah, maka berlaku kaedah "alljtihad la yunqadhu bi al-ljtihad"57 (suatu hasil ijtihad tidak bisa dibatalkan oleh hasil ijtihad yang lain). Walaupun begitu, dalam tataran praktisnya pada kajian fikih, lebih utama menggunakan pendapat mayoritas (jumhur ulama). Di samping itu, dalil-dalil yang dikemukakan oleh jumhur ulama lebih kuat (rajih). Adapun yang motivasinya untuk menjaga prilaku mahasiswi muslimah, khususnya bagi mahasiswi penghafal Alquran yang dianggap akan lebih memudahkannya menghindari kontak langsung dengan laki-laki lain yang tidak memiliki keperluan mendesak, sehingga tidak mengganggu hafalannya, motivasi ini sifatnya sangat subjektif dan kondisional. Sebab banyak juga mahasiswi muslimah lainnya yang bisa dengan mudah menghafal Alquran tanpa harus menggunakan cadar. Ini tergantung dari cara mahasiswi muslimah tersebut bergaul, lingkungan tempat tinggalnya, aktifitasnya, dan metode yang digunakannya dalam menghafal Alquran. Kembali pada prinsip "Jika niatnya untuk mencapai yang halal, maka hukum sarananya halal", maka mengecek niat mahasiswi muslimah itu sesuatu yang sulit, karena letaknya di hati, dan niat itu bisa berubah sewaktu-waktu. Dalam kajian ilmu usul fikih, yang dinilai itu adalah perbuatan mukallaf (af'al al-mukallafîn). Niat seseorang tidak bisa diberi status hukum, kecuali niatnya itu sudah diimplementasikan dalam bentuk perbuatan. Maka kalaupun untuk memudahkan menghafal Alquran dijadikan motivasi, harus ada bukti bahwa mahasiswi muslimah tersebut benar-benar sedang proses menghafal Alquran. Dan bagi mereka bisa diterapkan pengecualian boleh menggunakan cadar, sehingga menjadi identitas khusus yang membedakannya dengan mahasiswi biasa. Tapi bagi yang tidak bisa membuktikannya, maka

57 Jalâl al-Dîn Abd al-Rahmân ibn Abi Bakr al Suyûthi, alAsybâh wa al-Nazhâ'ir fi al-Furû', (Mesir: Dâr Ihyâ al-Kutub al'Arabiyyah, t. th), h. 201. 
mereka harus tunduk pada aturan yang berlaku di kampus tempat mereka kuliah.

Ketiga, menyangkut akibat dari dari suatu perbuatan. Mengacu pada pendapat Ibnu Qayyim, dzarîah yang semula ditentukan mubah, namun terkadang membawa kepada kerusakan, tetapi kerusakannya lebih kecil daripada kebaikannya. Dengan maraknya pemahaman Islam eksklusif yang dianut muslimah bercadar, cenderung pada pemahaman kebenaran tunggal dan lainnya salah (mukhatti'at), ini menimbulkan kesenjangan antar mahasiswi yang bercadar dan tidak bercadar yang berpotensi menyebabkan kekakuan dalam interaksi sosial. Selanjutnya, dzarîah yang semula ditentukan mubah, tidak ditujukan untuk kerusakan, namun biasanya sampai juga kepada kerusakan, dan kerusakan itu lebih besar daripada kebaikannya. Aplikasinya pada penggunaan cadar di perguruan tinggi, walaupun pada asalnya hukumnya mubah dan tidak ditujukan untuk kerusakan, tapi melihat fenomena istri-istri terduga teroris yang semuanya bercadar, ditambah fakta mahasiswi muslimah bercadar yang mendukung khilafah, tentu ini bisa sampai pada akibat yang merusak, karena bisa menimbulkan kecurigaan, stigma negatif terhadap mahasiswi yang bersangkutan dan merugikannya secara pribadi. Di samping itu, paham radikal dan khilafah berpotensi membahayakan keutuhan negara kesatuan. Begitu juga dalam pelaksanaan hal-hal yang berkaitan dengan kegiatan akademik, misalnya dalam ujian masuk perguruan tinggi, proses perkuliahan, praktikum, dan ujianujian lainnya di perguruan tinggi yang rawan kecurangan dan tindak pemalsuan. Ini tentu dapat murusak citra atau nama baik kampus.

Oleh sebab itu, mengacu pada substansi sadd al-dzarîah sebagai upaya menutup jalan yang menuju kepada yang haram/dilarang oleh Islam sebagai tindakan preventif. maka kebijakan larangan bercadar di perguruan tinggi yang bertujuan untuk memberikan perlindungan bagi mahasiswi muslimah dari paham radikal, prilaku/ sikap eksklusif, menghindarkan mereka dari penyamaran laki-laki yang berniat jahat dengan menutupi identitasnya melalui cadar di kampus, dan antisipasi kecurangan dalam kegiatankegiatan akademik lainnya di perguruan tinggi, tentu larangan tersebut bisa diterima karena sesuai dengan konsep sadd al-dzarîah yang pada akhirnya akan membawa kemaslahatan bagi pribadi-pribadi mahasiswi muslimah itu sendiri dan integritas kampus. Penerapan sadd al-dzarîa ah dalam hal ini, mengkhususkan kepada sarana yang dapat membawa manusia kepada perbuatan maksiat/haram. Dengan demikian, walaupun pada mulanya sarana itu sendiri (penggunaan cadar) hukumnya mubah, tetapi karena sarana itu dikhawatirkan akan membawa ke arah perbuatan maksiat yang mengandung bahaya, maka sarana itu pun bisa diharamkan. Hal ini sejalan dengan kaedah "li al-wasâ'il hukm al-maqâsid." Hanya saja, tingkat keharamannya bukanlah haram mutlak (li zatihi), tapi haram karena faktor eksternal (li ghairihi), keharamannya biasa disebut dengan harâm li sadd al-dzarîâh.

Dengan demikian, larangan penggunaan cadar di perguruan tinggi ada justifikasinya melalui dalil sadd al-dzarîâh. Namun, dalam penerapannya, harus ada pengecualian-pengecualian dengan syarat-syarat tertentu agar memberi peluang bagi mahasiswi muslimah yang membutuhkannya. Sebab dalam ketentuan kaidah fikih disebutkan bahwa perbuatan yang diharamkan karena pertimbangan sadd al-zarîâh, maka bisa dibolehkan melakukannya jika ada kebutuhan atau kemaslahatan yang lebih kuat (ma hurrima li sadd al-dzarîah, ubîha li al mashlahat al-râjihah) $)^{58}$. Oleh sebab itu, ketentuan atau aturan tentang larangan penggunaan cadar di perguruan tinggi harus dibuat sedetil mungkin kriterianya, baik terkait dengan subjek, tempat, waktu, termasuk jika memungkinkan teknis untuk mengetahui motivasi atau tujuan wanita tersebut bercadar. Dengan begitu, maka larangan bercadar di kampus bisa berlaku efektif dan tujuannya bisa diraih, serta tidak bertentangan dengan kemaslahatan sebagai tujuan utama penerapan hukum Islam (maqâshid al-syarîah).

\section{Penutup}

Dari pembahasan terdahulu dapat disimpulkan bahwa latar belakang munculnya larangan

${ }^{8}$ Ali Ahmad al-Nadwi, al-Qawâ`id al-Fiqhiyyah, (Beirut: Dar al-Qalam, 1998), h. 155. 
menggunakan cadar di kampus perguruan tinggi, disebabkan oleh prilaku mahasiswi bercadar yang berafiliasi pada organisasi tertentu yang berpaham khilafah. Di samping itu, sikap keberagamaan yang cenderung eksklusif ditambah fakta istri-istri para teroris yang semuanya bercadar, semakin membuat pihak kampus khawatir akan tumbuh suburnya radikalisme atas nama agama. Di kemudian hari berkembang pula kekhawatiran terhadap dampak lainnya yang bersifat akademik, meliputi kesulitan dalam proses pembelajaran dan potensi kecurangan dalam ujian-ujian dan kegiatan akademik lainnya yang dilaksanakan di perguruan tinggi.

Para ulama mazhab pada dasarnya sepakat tentang keharusan muslimah menutup auratnya berdasarnya Alquran dan hadis. Mazhab Hanafi, Maliki, dan Syafi'i sepakat berpendapat bahwa wajah wanita bukanlah aurat. Hanya mazhab Hambali yang berpendapat bahwa seluruh tubuh wanita, termasuk wajah adalah aurat. Untuk di dalam salat, semua mazhab juga sepakat tentang kebolehan wanita membuka wajahnya. Tapi untuk di luar salat hanya mazhab Hambali yang mewajibkan menutup wajah bagi wanita dengan menggunakan cadar. Sedangkan tiga mazhab yang lain mayoritas berpendapat hukumnya sunah, dan bisa menjadi wajib jika dikhawatirkan menimbulkan fitnah, terutama bagi wanita yang cantik.

Dengan demikian, dapat dipahami bahwa hukum bercadar bagi muslimah di luar salat, termasuk di kampus, bagian dari kategori masalah khilafiah. Dalam masalah ini, terbuka peluang ijtihad baru di dalamnya untuk mencapai kemaslahatan di dunia dan akhirat. Oleh sebab itu, kebijakan perguruan tinggi yang melarang mahasiswinya untuk bercadar di kampus, selama didasari keyakinan setelah penelitian yang akurat dan alasan yang kuat serta nyata dampak positifnya, baik bagi perguruan tinggi maupun mahasiswi itu sendiri, ini bisa dibenarkan berdasarkan dalil sadd al-dzarîah, sebagai langkah preventif dan antisipatif untuk mencegah potensi bahaya dan kerusakan (mudarat dan mafsadat) yang akan ditimbulkan dari pemakaian cadar tersebut selama di kampus.

\section{Pustaka Acuan}

Abidin, Ibnu, Hâsyiah Radd al Muhtar 'ala al-Durr al-Mukhtâr Syarh Tanwir al Abshâr, Riyadh: Dar al-Alam al-Kutub, t.th., Juz 3.

Alauddin, Muhammad bin Aly al-Haskafy, Al-Durr Al Mukhtâr Syarh Tanwir al-Abshâr, Lebanon: Dar al-Kutub al-Ilmiyah, $1423 \mathrm{H}$, Juz 2.

Andiko, Toha, "Reinterpretasi Sanksi Pidana Islam (Studi terhadap Pemikiran Prof. KH. Ibrahim Hosen, LML)", Jurnal Madania, Vol. XVIII, No. 2, Desember 2014

Arabi, Ibn al-', Ahkâm al-Qur'ân, Beirut: Dar alKutub, 2008, Juz 3.

Arfa, Faisar Ananda, Wanita Dalam Konsep Islam Modernis, Jakarta: Pustaka Firdaus, 2014.

Audah, Hasan al-', al-Mar'ah al-'Arabiyah Fi al-Din wa al-Mujtama', Beirut: al-Ahaly, 2000.

Bahuti, Syaikh Manshur ibn Yunus al-, Al-Raudhu al-Murbi' Syarhu Zâd al-Mustaqni', Mesir: Dar al-Hadits, t.th.

Baidan, Nashruddin, Tafsir bi al-Ra'yi,Yogyakarta: Pustaka Pelajar, 2009.

Banani, Al-'Allamah al-, Hâsyiyah al-'Allâmah al-Banani 'ala Syarh al-Mahalli 'ala Syarh Jam' al-Jawâmi', Mesir: Musthafa al-Halabi, 1938, Juz I.

Buthi, Ramadhan al-, Ilâ Kulli Fatat Tu'min Billah, Damaskus: Maktabah Al-Farabi, t.th.

Dardiri, Abi al-Barakat Ahmad al-, Syarh al-Kabir ‘ala Mukhtashar al-Khalil, Mesir: Dar al-Ma`arif, t.th., Vol. I.

Dimasyqi, Taqiyyudin Abu Bakar bin Muhammad al-Husaini al-, Kifâyat al-Akhyâr fi Halli Ghâyat al-Ikhtishâr, Damaskus: Dar al-Basya'ir, 2001, Cet. ke-9.

Era Muslim, Ulama Mesir Mendukung Larangan Cadar di Mesir, dikutip dari https://www. eramuslim.com/berita/dunia-islam/pelarangancadar-di-mesir-didukung-ulama-terkemuka. htm\#, diakses tanggal 29 Februari 2018

Hosen, Ibrahim, "Peranan Lembaga ljtihad Dalam Pengembangan Hukum Islam", Makalah disampaikan pada Halaqah Ilmiah Alumni Timur Tengah, Jakarta, 28 Mei 1989.

http://jateng.metrotvnews.com/peristiwa/ Rb1ZdRYk-larangan-cadar-bermula-dari-fotohti-di-kampus, diakses tgl 5 April 2018.

https://jurnalislam.com/guru-besar-uin-bandunglarangan-cadar-bertentangan-dengan-fungsiperguruan-tinggi/ diakses tanggal 21 Maret 2018 
https://www.kiblat.net/2018/03/17/iain-bukittinggibersikukuh-larang-cadar-di-kampus/, diakses 1 April 2018

https://www.voaindonesia.com/a/banyak-pihaktentang-larangan-pemakaian-cadar-di-uni-sunankalijaga-/4288811.html, diakses 29 Maret 2018 Jamal, Sulaiman ibn Umar ibn Mansur al-Ujaili al-Azhari al-, Futuhat al-Wahhâb bi Taudhih Syarh Manhaj al-Thullâb (Hâsyiyat al-Jamâl Alâ' Syarh al Minhaj), Mesir: Dar Ihya al-Turats al-Arabi, t. th.

Jauzi, Abu al-Faraj al-, Zâd al-Masir fi 'llm al-tafsir, Beirut: Dar Ibn Hazm, 2002, Cet. ke-1, Juz 6.

Lintang Ratri, "Cadar, Media, dan Identitas Perempuan Muslim", Jurnal Forum, Universitas Diponegoro Semarang, Vol. 39, No. 2, 2017.

Mahrus, Moh., "Aplikasi Al-dzarîaahdan al-Halah Perspektif Hukum Islam”, Jurnal Hukum islam IAIN Pekalongan, Oktober 2009.

Maqdisi, Muhammad ibn Muflih al-, Al Furu', Damaskus: Bait al-Afkar, t.th.

Muaidi, "Sadd al-dzarî̀ah dalam Hukum Islam", Tafaqquh: Jurnal Hukum Ekonomi Syariah dan Ahwal Syakhsiyah, Vol. 1, No. 2, Desember 2016.

Muhammad ibn Isa Abu Isa al-Tirmidzi, Sunan alTirmidzî, Beirut: Dar Ihya al-Turâts al-`Arabi, t.th, Juz IV.

Muhammad, Zainuddin ibn Ibrahim ibn, Al-Bahr al-Ra'iq Syarh Kanz al-Daqâ'iq, Iskandaria: Dar al-Iman, 1990.

Nadwi, Ali Ahmad al-, al-Qawa`id al-Fiqhiyyah, Beirut: Dar al-Qalam, 1998.

Qurthubi, Muhammad ibn Ahmad ibn Abi Bakr Farh al-, al-Jâmi' li Ahkâm al-Qur'ân, Mesir: Dar al-Sya'bi, $1372 \mathrm{H}$.

Sayis, Muhammad Ali al-, Tafsîr Ayât al-Ahkâm, Beirut: Dâr al-Fikr, t. th.

Shaleh, K.H.Q., dkk, Asbabun Nuzul, Bandung: Diponegoro, 2017.

Shihab, Jilbab Pakaian Wanita Muslimat, Jakarta: Lentera Hati, 2014.
Shihab, Muhammad Quraish, Wawasan Al-Qur'an, Bandung: Mizan, 2013, Cet. ke-19.

Suyûthi, Jalâl al-Dîn Abd al-Rahmân ibn Abi Bakr al-, al-Asybâh wa al-Nazhâ'ir fi al-Furû', Mesir: Dâr Ihyâ al-Kutub al-'Arabiyyah, t. th.

Syafi'i, Syamsuddin Abu Abdillah Muhammad bin Qasim al-, Fath al-Qarib, Beirut: Dar al-Kutub al-IImiyah, t. th.

Syaranbalali, Abu al-Ikhlas al-Hasn ibn Ammar ibn Ali ibn Yusuf al-, Nur al-Idhâh, Beirut: Dar al-Fikr, t.th.

Syarifuddin, Amir, Ushul Fiqh, Jakarta: Logos Wacana Ilmu, 2013, Cet. ke-11, Jilid I,

Syarwani, Abdul Hamid al-, Hâsyiah al-Syarwani 'Alâ Tuhfatul Muhtâj, Maktabah al-Tijariyah Kubra, t. th., Juz 2.

Syuqqah, Abdul Halim Abu, Al-Niqâb fi Syari'at al-Islam, Beirut: Dar al-Fikr, 2008. , Tahrir al-Mar'ah fi 'Ashr ar-Risalah, Vol. IV.

Tempo, Gelar atau Cadar?, dikutip dari https:// majalah.tempo.co/read/77163/gelar-ataucadar, diakses 21 Februari 2018.

Thanthawi, Muhammad Sayyid, al-Tafsir al-Wasith Li al-Qur'ân al-Karim, Kairo: Dar al-Sa'adah, 1985, Juz XI.

Ubadi, Ahmad ibn Qasim al-, Hâsyiah ibn Qasim 'Alâ Tuhfat al-Muhtâj, Beirut: Dar al-Kutub al-IImiyah, t. th., Juz III.

Utsaimin, Muhammad bin Shalih al-, Fatâwâ Nurun 'Ala al-Darb, Edisi CD Maktabah Syamilah

Zaid, Bakar bin Abdullah Abu, Menjaga Kehormatan, Jakarta: al-Safwa, 2013.

Zarqani, Muhammad Abd al-Baqiy bin Yusuf bin Ahmad bin Syihab al-Din bin Muhammad al-, Syarh Al-Zarqâni ‘ala Muwattha' Imam Malik, Beirut: Dar al-Ma'rifah, 1978, Jilid IV.

Zuhaili, Wahbah al-, al-Wasith fi Ushûl al-Figh alIslâmi, Damaskus: Dâr al-Kitâb, 1978. , Ushûl al-Fiqh al-Islâmi, Damsyiq: Dar alFikr, 1986, Juz II. 